\title{
Community Structure of Lumbricidae in Permanent Grassland and Arable Land
}

\author{
Anna Mazur-Pączka1*, Grzegorz Pączka', Joanna Kostecka', Mariola Garczyńska', \\ Agnieszka Podolak', Renata Szura ${ }^{1}$ \\ 1 Department of Natural Theories of Agriculture and Environmental Education, Faculty of Biology and Agriculture, \\ University of Rzeszow, Cwiklinskiej 1a, 35-601 Rzeszow, Poland \\ *Corresponding autor: anamazur@ur.edu.pl
}

\begin{abstract}
Lumbricidae play a key role in the soil environment as "the ecosystem engineers". They participate in all the categories of services provided by ecosystems. In agricultural areas, the conventional intensive farming practices have led to a significant decline in the biological diversity of soils including earthworms. In this study, we attempted to characterize the community structure of earthworms in permanent grassland and arable land of the Didactic \& Experimental Station of Rzeszów University in Krasne near Rzeszów. Similar densities of earthworms were observed in the grassland and in the arable land $\left(101.01 \pm 18.03\right.$ ind. $\cdot \mathrm{m}^{-2}$ and $82.12 \pm 18.26$ ind. $\cdot \mathrm{m}^{-2}$, respectively) $(\mathrm{p}>0.05)$ as well as a similar biomass of Lumbricidae $\left(77.72 \pm 15.30 \mathrm{~g} \cdot \mathrm{m}^{-2}\right.$ and $\left.54.34 \pm 11.72 \mathrm{~g} \cdot \mathrm{m}^{-2}\right)(\mathrm{p}>0.05)$. In the research, 7 species of earthworms were found in the permanent grassland and 6 representatives of Lumbricidae were identified in the arable land. The identified earthworms represented all three main morpho-ecological groups. The density and biomass of epi-endogeic earthworm L. rubellus and the anecic species of $L$. terrestris were shown to be higher $(p<0.05)$ in the grassland as compared to the arable land. In order to protect Lumbricidae and to sustain the beneficial role of earthworms in an ecosystem, it is necessary to monitor the negative changes in populations of earthworm species attributed to various farming practices.
\end{abstract}

Keywords: earthworms, biodiversity, agricultural areas, dominance, frequency, Shannon-Wiener diversity index, dominance values of Berger-Parker

\section{INTRODUCTION}

The size and quality of arable crops are the benchmarks of soil fertility. Soil fertility is determined by the physical, chemical and biological properties of soil and by the soil organisms [Barrios et al. 2007]. Earthworms constitute a significant share of soil organisms and, owing to their activity in soil, are referred to as 'ecosystem engineers' [Jouquet et al. 2006]. Lumbricidae contribute to the development of specific soil properties by improving its structure and increasing the field capacity [Zangerlé et al. 2011, Schon et al. 2017]. They also influence the dynamics of the organic matter [Fonte et al. 2009, 2010, Amosse et al. 2015] by delivering and retaining nutrients necessary for the growth and development of plants [van Groenigen et al. 2014, Manono 2016] as well as by regulating the size of pest populations [Bertrand et al. 2015]. Therefore, the activity of Lumbricidae in the soil environment has a positive influence on the production of food crops, energy crops, and fibre crops.

In agricultural areas, conventional intensive farming practices have led to a significant decline in the biological diversity of soils [Briones, Schmidt 2017]. Ploughing contributes to a reduction in the population size and diversity of species of earthworms, as it physically disturbs the environment of earthworms and causes mechanical damage to earthworms, especially epigeic and anecic ones. Mortality rates -e.g. due to the injury caused by field ploughing - are estimated at $50 \%$. The extent of these negative effects may be much greater, depending on the type and frequency of cultivation 
[Curry 2004, Capowiez et al. 2009, van Capelle et al. 2012]. Harvest is another factor which further exacerbates the exposure to stress factors across farming fields, as it involves the removal of vegetation which creates a specific micro-climate and provides shade for the soil surface. If the plant layer is removed, the soil moisture decreases, and earthworms are exposed to direct sunlight. Various studies conducted in agrocenoses also proved that the use of chemical plant protection agents reduced the population size and biomass of earthworms [Pelosi et al. 2013, Datta et al. 2016].

The objective of this paper was to determine the qualitative and quantitative structure of earthworms in the grassland and in the arable land of the Didactic \& Experimental Station of Rzeszów University in Krasne near Rzeszów.

\section{MATERIAL AND METHODS}

The study was conducted at the Didactic \& Experimental Station of Rzeszów University in Krasne in two growing seasons. Two ecosystems were selected for the analysis: permanent grassland (50a) and arable land (5 ha) (Table 1), in both of which numerous samples were collected for the analysis.

The cultivation activities employed in the studied ecosystems were also examined. Five years before the start of the research, goat rue (Galega orientalis Lam.), orchard grass (Dactylis glomerate L.), false oat-grass (Arrhenatherum elatius L.), meadow fescue (Festuca pratensis Huds.), and red clover (Trifolium pratense L.) were planted in the grassland.

The arable land was planted with winter rye (variety: Dańkowskie Amber; Danko sp. z o.o.; $90 \mathrm{~kg} \cdot \mathrm{ha}^{-1}$ ) (first research season) and barley (scond research season) (variety Stratus; Strzelce sp. z o.o.; $\left.140 \mathrm{~kg} \cdot \mathrm{ha}^{-1}\right)$. Low doses of phosphorus and potassium fertilizers $\left(70 \mathrm{~kg} \mathrm{P} \cdot \mathrm{ha}^{-1}\right.$ and $70 \mathrm{~kg}$ $\mathrm{K} \cdot \mathrm{ha}^{-1}$ ) and a nitrogen fertilizer (ammoniac saltpetre $34 \% ; 30 \mathrm{~kg} \mathrm{~N} \cdot \mathrm{ha}^{-1}$ ) were used before planting.

The soil temperature and moisture were measured $0-20 \mathrm{~cm}$ below the soil surface and at a lower level, alongside the air temperature measurements conducted at each research site. The soil moisture was determined using oven-drying method at $105^{\circ} \mathrm{C}$ [PN ISO 11465:1999]. Additionally, the soil samples were collected at each research site for tests of soil $\mathrm{pH}-\mathrm{KCl}$, organic carbon (based on the Tiurin approach with Nikitin's modification) [Nikitin, Fishman 1969], and absorbable forms of phosphorus, potassium and magnesium according to the Mehlich III method [Mehlich 1984].

The combined Zajonc method [1970] according to ISO [EN ISO 23611-1:2006] was the basic method for the earthworm search. The earthworms were searched manually by sorting $25 \times 25 \times 25 \mathrm{~cm}$ soil blocks. The earthworms were extracted from the deeper layers of the profile by slowly flooding a hole with 10 litres of $0.4 \%$ formalin solution. The samples were collected from April to October (first research season) and from April to November (second research season). According to the Zisci recommendations [1962], eight samples were collected each time at the research sites, randomly selected by tossing a metal frame.

The following indicators were applied to assess the communities of Lumbricidae:

- dominance (D), $\mathrm{D}=\mathrm{na} / \mathrm{n}$, where $n a$ is the number of specimens of the species $a$ in all tested samples, $n$ is the number of specimens of the tested community of species in all samples,

- frequency (C), C =q/Q, where $q$ is the number of samples in which the species $a$ is present, $\mathrm{Q}$ is the number of samples in the study batch,

Table 1. Characteristics of Lumbricidae sampling sites in Krasne

\begin{tabular}{|c|c|c|}
\hline Site & Soil type & Soil properties \\
\hline $\begin{array}{l}\text { Grassland } \\
\text { N } 50^{\circ} 02^{\prime} 53.9^{\prime \prime} \\
\text { E } 022^{\circ} 03^{\prime} 16.8^{\prime \prime}\end{array}$ & $\begin{array}{l}\text { Brown earth of loess-origin, granulometric } \\
\text { composition of ordinary dust, average agronomic } \\
\text { category (soil of wheat, good complex, soil class } \\
\text { IIla) }\end{array}$ & $\begin{array}{l}\text { Mean soil temperature } \\
(0-20 \mathrm{~cm}) 14.1 \pm 3.4{ }^{\circ} \mathrm{C} ;(<20 \mathrm{~cm}) 13.9 \pm 3.3^{\circ} \mathrm{C} \\
\text { Mean soil moisture } \\
(0-20 \mathrm{~cm}) 19.9 \pm 6.1 \% ;(<20 \mathrm{~cm}) 19.8 \pm 6.4 \% \\
\mathrm{pH} \text { in } \mathrm{KCl} 5.95 ; \text { humus } 1.91 \% ; \\
11.1 \mathrm{mg} \mathrm{P} \mathrm{P}_{5} / 100 \mathrm{~g} \mathrm{s.m} . ; 18 \mathrm{mg} \mathrm{K} \mathrm{O}_{2} \mathrm{O} / 100 \mathrm{~g} \text { s.m.; } 2.6 \\
\mathrm{mg} \mathrm{Mg} / 100 \mathrm{~g} \text { s.m. }\end{array}$ \\
\hline $\begin{array}{l}\text { Arable land } \\
\text { N } 50^{\circ} 03^{\prime} 13.9^{\prime \prime} \\
\text { E } 022^{\circ} 05^{\prime} 26.7^{\prime \prime}\end{array}$ & $\begin{array}{l}\text { Brown earth of loess-origin, granulometric } \\
\text { composition of ordinary dust, average agronomic } \\
\text { category (soil of wheat, good complex, soil class } \\
\text { IIla) }\end{array}$ & $\begin{array}{l}\text { Mean soil temperature } \\
(0-20 \mathrm{~cm}) 13.9 \pm 3.9^{\circ} \mathrm{C} ;(<20 \mathrm{~cm}) 13.8 \pm 3.9^{\circ} \mathrm{C} \\
\text { Mean soil moisture } \\
0-20 \mathrm{~cm}) 19.7 \pm 6.2 \% ;(<20 \mathrm{~cm}) 19.1 \pm 6.7 \% \\
\text { pH in } \mathrm{KCl} 5.78 ; \text { humus } 1.52 \% ; 9.3 \mathrm{mg} \mathrm{P}_{2} \mathrm{O}_{5} / 100 \mathrm{~g} \\
\text { s.m.; } 16 \mathrm{mg} \mathrm{K} \mathrm{O}_{2} / 100 \mathrm{~g} \mathrm{~s} . \mathrm{m} . ; 2.1 \mathrm{mg} \mathrm{Mg} / 100 \mathrm{~g} \mathrm{s.m} \text {. }\end{array}$ \\
\hline
\end{tabular}


- Shannon-Wiener $(\mathrm{H}), H=-\Sigma p_{i} \ln p_{i}$, where $p_{i}$ is the number of specimens of a particular species vs population size of all organisms,

- Berger-Parker (d), $d=N_{\text {Max }} / N$, where $\mathrm{N}_{\text {Max }}$ is the maximum number of identified species, and $\mathrm{N}$ is the number of all specimens per sample.

The data were presented as mean \pm standard deviation (SD). The results were analysed statistically in STATISTICA v. 10 software, using t-student test or Mann-Whitney U test.

\section{RESULTS}

Seven species of earthworms were found in the permanent grassland and six representatives of Lumbricidae were identified in the arable land (Table 2). The earthworms identified represented all three main morpho-ecological groups (Table 2). In the grassland, the epigeic group was represented by two species: $D$. rubidus tenuis and $D$. octaedra. However, D. rubidus tenuis was the only epigeic species identified in the arable land. $L$. rubellus, an epi-endogeic earthworm, was found at both research sites. Three species of endogeic Lumbricidae: A. caliginosa, A. rosea and $O$. lacteum were identified in both grassland and arable land. Anecic earthworms - deep-burrowing earthworms - were represented by L. terrestris in both grassland and arable land.

A similar number of earthworms was observed in the grassland and in the arable land (101.01 \pm 18.03 ind. $\cdot \mathrm{m}^{-2}$ and $82.12 \pm 18.26$ ind. $\cdot \mathrm{m}^{-2}$, respectively) ( $p>0.05)$; the biomass of Lumbricidae was similar as well $\left(77.72 \pm 15.30 \mathrm{~g} \cdot \mathrm{m}^{-2}\right.$ and $\left.54.34 \pm 11.72 \mathrm{~g} \cdot \mathrm{m}^{-2}\right)(\mathrm{p}>0.05)$. No significant differences between the studied habitats were found in terms of the Shannon biological diversity index $(\mathrm{H})$ and the Berger-Parker dominance index (d) $(\mathrm{p}>0.05)($ Table 3$)$
The eudominant species of $A$. caliginosa, A. rosea, and L. terrestris, prevailed in the grassland communities. The dominants included L. rubellus and $O$. lacteum, while D. octaedra and D. rubidus tenuis were classified as subdominants. The eudominants in the arable land included two species: $A$. caliginosa, $A$. rosea, whereas the remaining species were classified as dominants (Table 4).

The highest prevalence $(100 \%)$ was reported for A. caliginosa, A. rosea and L. terrestris in the grassland, and for A. caliginosa $(100 \%)$ and A. rosea $(87 \%)$ in the arable land (Table 4$)$.

The density and biomass of epi-endogeic earthworm $L$. rubellus and the anecic species of $L$. terrestris were shown to be higher $(\mathrm{p}<0.05)$ in the grassland as compared to the arable land (Table 4).

\section{DISCUSSION}

The earthworms found in the arable land in Krasne (6 species), were also confirmed to be present in the nearby grassland ( 7 species), forming a rich lumbricofauna. This is also evident from the similar values of the Shannon biological diversity index $(\mathrm{H})$ and the Berger-Parker index (d) obtained for both habitats (Table 3). The diversity of earthworms found in the arable land in Krasne is superior to that observed in other studies of arable areas [Kostecka 1993, Makulec 2004, Smith et al. 2008], where only 1-2 species were found to be present. The richness of species living in the arable land in Krasne may be attributed to good planning and skillful use of land resources at the farm of the Rzeszów University. This includes low and average doses of mineral fertilization $\left(<100 \mathrm{~kg} \cdot \mathrm{ha}^{-1}\right)$ and an adequately planned crop rotation. These practices have a positive impact on soil fauna [Bengtsson et al. 2005]. Rescheduling the ploughing to summer (August of the first and second research season) could also contribute to the lesser negative impact of this

Table 2. Species structure of Lumbricidae from permanent grassland and arable land in Krasne

\begin{tabular}{|l|c|c|}
\hline \multicolumn{1}{|c|}{ Species of earthworm } & Permanent grassland & Arable land \\
\hline Dendrodrilus rubidus tenuis (Savigny 1826) a & + & + \\
\hline Dendrobaena octaedra (Savigny 1826) a & + & - \\
\hline Lumbricus rubellus (Hoffmeister 1843) ab & + & + \\
\hline Aporrectodea caliginosa (Savigny 1826) b & + & + \\
\hline Aporrectodea rosea (Savigny 1826) b & + & + \\
\hline Octolasion lacteum (Oerley 1881) b & + & + \\
\hline Lumbricus terrestris (L. 1758) c & + & + \\
\hline Number of species & + \\
\hline
\end{tabular}

$\mathrm{a}$ - epigeic earthworms, $\mathrm{ab}$ - epi-endogeic earthworms, $\mathrm{b}$ - endogeic earthworms, $\mathrm{c}$ - anecic earthworms 
Table 3. Earthworm community characteristics in permanent grassland and in arable land in Krasne

\begin{tabular}{|l|c|c|}
\hline Ecological parameters & Permament grassland & Arable land \\
\hline Earthworm density $\left[\right.$ ind. $\left.\cdot \mathrm{m}^{-2}\right]$ & $101.01^{\mathrm{a}} \pm 18.03$ & $82.12^{\mathrm{a}} \pm 18.26$ \\
\hline Earthworm biomass $\left[\mathrm{g} \cdot \mathrm{m}^{-2}\right]$ & $77.72^{\mathrm{a}} \pm 15.30$ & $54.34^{\mathrm{a}} \pm 11.72$ \\
\hline Shannon-Wiener diversity index $(\mathrm{H})$ & $0.6^{\mathrm{a}} \pm 0.18$ & $0.57^{\mathrm{a}} \pm 0.16$ \\
\hline Dominance values of Berger-Parker $(\mathrm{d})$ & $0.06^{\mathrm{a}} \pm 0.01$ & $0.07^{\mathrm{a}} \pm 0.02$ \\
\hline
\end{tabular}

a - statistically insignificant differences $(p>0.05)$

Table 4. Earthworm population characteristics from permanent grassland (PG) and arable land (AL) in Krasne

\begin{tabular}{|c|c|c|c|c|c|}
\hline \multicolumn{2}{|c|}{ Earthworm species } & $\begin{array}{c}\text { Dominance } \\
{[\%]}\end{array}$ & $\begin{array}{c}\text { Frequency } \\
{[\%]}\end{array}$ & $\begin{array}{c}\text { Density } \\
{\left[\text { ind. } \cdot \mathrm{m}^{-2}\right]}\end{array}$ & $\begin{array}{c}\text { Biomass } \\
{\left[\mathrm{g} \cdot \mathrm{m}^{-2}\right]}\end{array}$ \\
\hline \multirow{2}{*}{ D. rubidus tenuis } & PG & 3.33; subdominant & 26.67 & $4.75^{\mathrm{a}} \pm 3.37$ & $0.59^{a} \pm 0.43$ \\
\hline & $\mathrm{AL}$ & 5.41; dominant & 33.33 & $5.25^{\mathrm{a}} \pm 3.52$ & $0.67^{a} \pm 0.47$ \\
\hline \multirow{2}{*}{ D. octaedra } & $P G$ & 3.67; subdominant & 33.33 & $3.25 \pm 1.91$ & $0.51 \pm 0.30$ \\
\hline & $\mathrm{AL}$ & - & - & - & - \\
\hline \multirow{2}{*}{ L. rubellus } & PG & 5.96; dominant & 60.00 & $8.00^{\mathrm{a}} \pm 5.91$ & $3.28^{\mathrm{a}} \pm 2.68$ \\
\hline & $\mathrm{AL}$ & 6.83; dominant & 40.00 & $3.75^{b} \pm 3.09$ & $1.83^{\mathrm{b}} \pm 1.53$ \\
\hline \multirow{2}{*}{ A. caliginosa } & PG & 45.12; eudominant & 100.00 & $62.00^{\mathrm{a}} \pm 25.81$ & $30.32^{\mathrm{a}} \pm 13.50$ \\
\hline & $\mathrm{AL}$ & 52.91; eudominant & 100.00 & $49.5^{\mathrm{a}} \pm 22.03$ & $21.78^{a} \pm 10.47$ \\
\hline \multirow{2}{*}{ A. rosea } & $P G$ & 23.12; eudominant & 100.00 & $19.50^{\mathrm{a}} \pm 7.80$ & $10.99^{\mathrm{a}} \pm 4.67$ \\
\hline & $\mathrm{AL}$ & 18.83; eudominant & 86.70 & $15.00^{\mathrm{a}} \pm 9.93$ & $6.81^{\mathrm{a}} \pm 4.93$ \\
\hline \multirow{2}{*}{ O. lacteum } & $P G$ & 5.41 ; dominant & 40.00 & $6.25^{\mathrm{a}} \pm 2.88$ & $3.63^{a} \pm 1.86$ \\
\hline & $\mathrm{AL}$ & 7.38; dominant & 40.00 & $7.25^{\mathrm{a}} \pm 3.96$ & $3.97^{\mathrm{a}} \pm 2.33$ \\
\hline \multirow{2}{*}{ L. terrestris } & PG & 13.61; eudominant & 100.00 & $15.50^{a} \pm 8.97$ & $40.04^{a} \pm 25.80$ \\
\hline & $\mathrm{AL}$ & 8.88; dominant & 60.00 & $6.25^{\mathrm{b}} \pm 4.76$ & $16.99^{b} \pm 13.99$ \\
\hline
\end{tabular}

${ }^{a}$ - statistically insignificant differences $(p>0.05){ }^{b}-$ statistically significant differences $(p<0.05)$

agricultural practice on Lumbricidae. At this time of the year, the anecic species can usually be found in the deeper layers of soil, whereas the endogeic earthworms tend to enter the state of anabiosis (because of low water levels). Moreover, the vicinity of the grassland with a more stable habitat facilitates permanent migration of Lumbricidae from that ecosystem.

According to Coleman et al. [2004], the density of earthworm populations in grasslands of the moderate climate zone ranges from 50 to 200 specimens per $\mathrm{m}^{2}$. The population size of Lumbricidae in the grassland in Krasne $\left(101.01 \pm 18.03\right.$ ind. $\left.\cdot \mathrm{m}^{-2}\right)$ falls within this range. Kanianska et al. [2016] $\left(120\right.$ ind. $\left.\cdot \mathrm{m}^{-2}\right)$ report similar data collected in a permanent grassland area in Slovakia.

However, the data regarding biomass can be interpreted differently. In the 1980 s, the volume of biomass in meadow and grassland soils in Poland was estimated at $300 \mathrm{~g} \cdot \mathrm{m}^{-2}$ [Kasprzak 1986]. Kostecka [1992] reported a biomass of 122 $\mathrm{g} \cdot \mathrm{m}^{-2}$ in the meadows in Rajskie in the region of Subcarpathia (Podkarpacie). The most recent studies of Rożen et al. [2013] on the meadows in Silesian Beskids (Beskid Śląski) highlands revealed a biomass of $50-60 \mathrm{~g} \cdot \mathrm{m}^{-2}$. The meadow in Krasne was found to contain a similarly low level of biomass of $77.72 \pm 15.30 \mathrm{~g} \cdot \mathrm{m}^{-2}$ (Table 3). According to other studies, the arable land is characterised by lower density and biomass of Lumbricidae compared to the habitats not exposed to direct interference [Smith et al. 2008, Feijoo et al. 2011, Felten, Emmerling 2011]. This tendency has not been confirmed in the study conducted in Krasne. Similar populations of earthworms in terms of size and biomass levels were found in the arable land of rye and barley and in the grassland (Table 3). Kasprzak [1986] recorded a biomass of earthworms within the range of $20-150 \mathrm{~g} \cdot \mathrm{m}^{-2}$ in arable lands in 1980s. Witkowski [1983] recorded a biomass of $4.1-5.3 \mathrm{~g} \cdot \mathrm{m}^{-2}$ in the fields planted with cereals and potatoes, whereas Ryl [1984] recorded $4.7 \mathrm{~g} \cdot \mathrm{m}^{-2}$ of biomass in the arable land of wheat. The present study in the arable land in Krasne revealed a biomass of more than $54.34 \pm 11.72 \mathrm{~g}$. $\mathrm{m}^{-2}$ (Table 3). This may point at the involvement of many factors, both biotic and abiotic, but it can also be attributed to the aforementioned good practices of agrocenosis in Krasne.

The endogeic species A. caliginosa and A. rosea prevailed in the communities identified at both research sites in the Didactic \& Experimental Station of the Rzeszów University. These are common eurytopic species tolerant to the agricultural 
disturbances in soil. A. caliginosa was usually reported as the most abundant species in the arable land. This finding was confirmed by many authors [e.g. Ivask et al. 2007, Lapied et al. 2009, Lüscher et al. 2014, Kanianska et al. 2016].

The population and biomass of deep-burrowing earthworms of L. terrestris were found to be superior in the grassland compared to the arable land. This may be due to the fact that ploughing destroys the earthworm burrows and tunnels in the arable land, thus causing the earthworms of this species to use their energy resources to reconstruct the tunnels and for other life activities [Monroy 2006]. Ploughing also limits the availability of nutrients which are absorbed from the soil surface to the underground tunnels. Similar tendencies were described by Whalen [2004].

Epigeic earthworms of $D$. octaedra species present on the nearby meadow were found in the arable land. Epigeic earthworms are usually most exposed to farming practices which transform the surface layers of soil to a large extent. It is assumed that the epigeic species are more numerous in the environments not exposed to the agricultural interference [Haynes et al. 2002].

\section{CONCLUSIONS}

A similar large population and biomass of earthworms along with comparable values of the Shannon-Wiener biological diversity index and the Berger-Parker dominance index were identified in the permanent grassland and in the arable land of the Didactic \& Experimental Station of the Rzeszów University in Krasne. Eudominant A. caliginosa and $A$. rosea prevailed in the community in the arable land. Another eudominant, $L$. terrestris, was also indentified in the permanent grassland community.

1. Modern agriculture, apart from the profits derived from land cultivation, should aim at supporting the biological diversity of soil organisms. In order to protect Lumbricidae and to sustain the beneficial role of earthworms in an ecosystem, it is necessary to monitor the negative changes in the populations of earthworm species attributed to various farming practices.

2. Earthworms are a bio-indicator of the soil environment quality. The representatives of all three morpho-ecological groups were found in both ecosystems, which is indicative of good planning and skillful use of land resources at the farming facilities of the Rzeszów University.

\section{REFERENCES}

1. Amosse J., Turberg P., Kohler-Milleret R., Gobat J., Le Bayon R. 2015. Effects of endogeic earthworms on the soil organic matter dynamics and the soil structure in urban and alluvial soil materials. Geoderma, 243-244, 50-57.

2. Barrios E. 2007. Soil biota, ecosystem services and land productivity. Ecological Economics, 64, 269-285.

3. Bengtsson J., Ahnström J., Weibull C. 2005. The effect of organic agriculture on biodiversity and abundance: A meta-analysis. Journal of Applied Ecology, 42, 261-269.

4. Bertrand M., Blouin M., Barot S., Charlier A., Marhcnad D., Roger-Estrade J. 2015. Biocontrol of eyespot disease on two winter wheat cultivars by an anecic earthworm (Lumbricus terrestris). Applied Soil Ecology, 96, 33-41.

5. Briones M.J.I., Schmidt O. 2017.Conventional tillage decreases the abundance and biomass of earthworms and alters their community structure in a global meta-analysis. Global Change Biology, 23(10), 4396-4419.

6. Capowiez Y., Cadoux S., Bouchant P., Ruy S., Estrade J.R., Richard G., Boizard H. 2009. The effect of tillage type and cropping system on earthworm communities, macroporosity and water infiltration. Soil and Tillage Research, 105, 209-216.

7. Coleman D.C., Crossley D.A., Hendrix P.F. 2004. Fundamentals of soil ecology. Elsevier Academic Press, Brulington.

8. Curry J.P. 2004. Factors affecting the abundance of earthworms in soils. [In:] Earthworm Ecology. [eds.] C. Edwards, CRC Press, Boca Raton.

9. Datta S., Singh J., Singh S., Singh J. 2016. Earthworms, pesticides and sustainable agriculture: a review. Environmental Science and Pollution Research, 23(9), 8227-8243.

10. EN ISO 23611-1:2006. Soil quality. Sampling of soil invertebrates. Part 1. Hand-sorting and formalin extraction of earthworms. Geneva. Switzerland.

11. Feijoo A., Carvajal A.F., Zúñiga M.C., Quintero H., Fragoso C. 2011. Diversity and abundance of earthworms in land use systems in central-western Colombia. Pedobiologia, 54, 69-75.

12. Felten D., Emmerling C. 2011. Effects of bioenergy crop cultivation on earthworm communitiesm - A comparative study of perennial (Miscanthus) and annual crops with consideration of graded land-use intensity. Applied Soil Ecology, 49, 167-177.

13. Fonte S.J., Barrios E., Six J. 2010. Earthworm impacts on soil organic matter and fertilizer dynamics in tropical hillside agroecosystems of Honduras. Pedobiologia, 53(5), 327-335.

14. Fonte S.J., Winsome T., Six J. 2009. Earthworm populations in relation to soil organic matter dy- 
namics and management in California tomato cropping systems. Applied Soil Ecology, 41, 206-214.

15. Haynes R.J., Dominy C.S., Graha M.H. 2002. Effect of agricultural land use on soil organic matter status and the composition of earthworm communities in KwaZulu-Natal, South Africa. Agriculture, Ecosystems and Environment, 95, 453-464.

16. Ivask M., Kuu A., Sizov E. 2007. Abudance of earthworm species in Estonia arable soils. Soil Biology, 43, 39-42.

17. Jouquet P., Dauber J., Lagerlof J., Lavelle P., Lepage, M. 2006. Soil invertebrates as ecosystem engineers: Intended and accidental effects on soil and feedback loops. Applied Soil Ecology, 32, 153-164.

18. Kasprzak K. 1986. Soil Oligochaeta III - The family of Earthworms (Lumbricidae). The keys to indicate the invertebrates of Poland. PWN, Warsaw (in Polish).

19. Kanianska R., Jad'ud'uová J., Makovníková J., Kizeková M. 2016.Assessment of Relationships between Earthworms and Soil Abiotic and Biotic Factors as a Tool in Sustainable Agricultural. Sustainability, 8(9), 906.

20. Kostecka J. 1992. Earthworms (Lumbricidae, Oligochaeta) identified in some points of the Western Bieszczady. Scientific Agricultural and Forestry. Natural Basics of Agricultural Production, 1, 110-118.

21. Kostecka J. 1993. Numbers, biomass, and species composition of earthworms (Lumbricidae) of arable land under drought conditions. Leading Problems of Agricultural Development in the South-East Poland. Some Studies on Agriculture in South-Eastern Poland, 5, 199-206 (in Polish).

22. Lapied E., Nahmani J., Rousseau G.X. 2009. Influence of texture and amendments on soil properties and earthworm communities. Applied Soil Ecology, 43, 241-249.

23. Lüscher G., Jeanneret P., Schneider M.K., Turnbull L.A., Arndorfer M., Balázs K., Báldi A., Bailey D., Bernhardt K.G., Choisis J.P., Elek Z., Frank T., Friedel J.K., Kainz M., Kovács-Hostyánszki A., Oschatz M.L., Paoletti M.G., Papaja-Hülsbergen S., Sarthou J.P., Siebrecht N., Wolfrum S., Herzog F. 2014. Responses of plants, earthworms, spiders and bees to geographic location, agricultural management and surrounding landscape in European arable fields. Agriculture, Ecosystems and Environment, 186, 124-134.

24. Makulec G. 2004. Lumbricidae communities in several years old midfield shelterbelt (Turew Region, Western Poland). Polish Journal of Ecology, 52(2), 173-179.

25. ManonoB.2016.Agro-ecologicalroleofearthworms (Oligochaetes) in sustainable agriculture and nutrient use efficiency: A Review. Journal of Agriculture and Ecology Research International, 8(1), 1-18.

26. Mehlich A. 1984. Mehlich 3 soil test extractant: A modification of Mehlich 2 extractant. Communications in Soil Science and Plant Analysis, 15, 1409-1416.

27. Monroy F., Aira M., Dominguez J., Velando A.
2006. Seasonal population dynamics of Eisenia fetida (Savigny, 1826) (Oligochaeta, Lumbricidae) in the field. Population Biology, 329, 912-915.

28. Nikitin V., Fishman V. 1969. On the improvement of methods for determination of soil carbon. Chemistry in Agriculture, 3, 76-77.

29. Pelosi C., Barot S., Capowiez I., Hedde M., Vandenbulck F. 2013. Pesticides and earthworms. A review. Agronomy for Sustainable Development, 34(1), 199-228.

30. PN-ISO 11465:1999. Soil quality - Determination of soil dry matter and water content in soil in terms of dry soil mass - weight metod (in Polish).

31. Rożen A., Mysłajek R.W., Sobczyk Ł. 2013. Altitude versus vegetation as the factors Influencing the diversity and abundance of earthworms and other soil macrofauna in montane habitat (Silesian Beskid Mts, Western Carpathians). Polish Journal of Ecology, 61(1), 145-156.

32. Ryl B. 1984. Comparison of communities of earthworms (Lumbricidae) occurring in diffrent ecosystem of agricultural landscape. Polish Ecology, 2(1), 155-165 (in Polish).

33. Schon N.L., Mackay A. D., Gray R.A., Van Koten C., Dodd M.B. 2017. Influence of earthworm abundance and diversity on soil structure and the implications for soil services throughout the season. Pedobiologia, 62. 41-47.

34. Smith R.G., McSwiney C.P., Grandy A.S., Suwanwaree P., Snider R.M., Robertson G.P. 2008. Diversity and abundance of earthworms across anagricultural land-use intensity gradient. Soil and Tillage Research, 100, 83-88.

35. Van Capelle, C., Schrader, S., Brunotte, J. 2012. Tillage-inducedchanges in the func-tional diversity of soil biota: a review with a focus on German data. European Journal of Soil Biology, 50, 165-181.

36. Van Groenigen J.W., Lubbers I.M., Vos H.J.M., Brown G.G., De Deyn G.B., Groenigen K.J. 2014. Earthworms increase plant production: a metaanalysis. Scientific Reports, 4, 63-65.

37. Whalen J.K. 2004. Spatial and temporal distribution of earthworm patches in corn field and forest systems of southwestern Quebec, Canada. Applied Soil Ecology, 27, 143-151.

38. Witkowski T. 1983. Numbers and biomass of earthworms (Lumbricidae) under different crop rotation conditions. Annals of Soil Science, 34, 83-102 (in Polish).

39. Zajonc J. 1970. Grouping of earthworms (Lumbricidae) of the Carpathian region of Czechoslovakia. Biological Work, 120 (in Czech).

40. Zangerlé A., Pando A., Lavelle P. 2011. Do earthworms and roots cooperate to build soil macroaggregates? A microcosm experiment. Geoderma, 167-168, 303-309.

41. Zisci A. 1962. Determination of number and size of sampling unit for estimating lumbricid populations of arable soils. [In:]: Progress in soil zoology. [eds.] P.W. Murphy. Butterworths, London, 68-71. 